\title{
ヒト試料を用いた薬物相互作用の予測
}

\section{千葉 寛}

国立国際医療センター・研究所・臨床薬理部・ 薬物代謝動態研究室

Prediction of drug-drug interactin using human materials

\section{Kan Chiba}

Division of Drug Metabolism \& Disposition, Deaprtment of Clinical Pharmacology, Research Institute, International Medical Center of Japan

薬物相互作用は、薬力学的相互作用と薬物動態学的相互作用に大 別され、薬物動態学的相互作用は、さらに吸収、分布、代謝、及び 排泄部位における相互作用に分けることができる。これらの相互作 用の中で最も頻度の高いものは、代謝部位における相互作用であり、 そのほとんどがチトクロームP450を介した相互作用である ${ }^{1.2) 。 ~}$

P450を介した相互作用は、頻度が高いだけではなく、テルフェナ ジンとマクロライド系抗生物質の相互作用、ミダゾラムとアゾール 系抗真菌剤の相互作用など、臨床的に問題となるものが多い。その ため、これらの相互作用を前臨床試験の段階で予測できれば、新規 医薬品使用時の患者のリスクを軽減させることが可能になるばかり でなく、有害な相互作用を起こさない化合物を選択することにより、 医薬品開発の効率を高めることができる ${ }^{3)} 。$

P450を介した相互作用は、阻害、誘導、その他、に分類され、そ の中で、阻害による相互作用の頻度が最も高い1.2)。P450を阻害す ることによって起きる相互作用には、1)同じP450分子種を競合する ことによって起きる相互作用、2)代謝物がP450と解離しにくい複合 体を作ることによる阻害、3）イミダゾール環の窒素等がP450のへム 部分に配位する事による阻害がある。誘導に関しては、抗てんかん 薬、リファンピシン、䝟煙によるクリアランス増加が問題になるこ とが多い。

開発中の医薬品が、どのような薬物により阻害、あるいは誘導を 
受けるかについては、その薬物が、どのようなヒトP450分子種で代 謝されるかを、明らかにする事によって、ある程度予測可能である ${ }^{31} 。$

例えば、開発中の医薬品の代謝に関わる主要なヒトP450分子種が、 CYP1A2であった場合、その薬物の代謝は、キノロン系の抗菌剤によ って阻害され、喫煙によって誘導を受ける。また、主要なP450分子 種がCYP3A4であった場合、その薬物の代謝は、マクロライド系の抗 生物質及びアゾール系の抗真菌剤により、阻害され、抗てんかん薬 及びリファンピシンにより、誘導を受けることが、予想される ${ }^{3)} 。$

この様な予測が可能になったのは、個々のヒトP450分子種を阻害、 あるいは誘導する薬物が、どのような薬物であるかが、ある程度明 らかになってきたためである。しかし、開発中の医薬品が、どの様 な薬物の代謝を阻害又は誘導をするかは、その薬物の代謝に関わる、 主要なP450分子種を明らにするだけでは、不十分である。

この場合は、その薬物の、各ヒトP450分子種に対する阻害定数と、 臨床用量を投与した際の、非結合型肝内濃度を知る必要がある。前 者は、ヒトP450発現系等を用いることで、推定できるが、後者につ いての予測は困難である場合が多い。

しかし、得られた阻害定数が極端に小さかったり、阻害が特定の P450分子に対して非可逆的であったり、複数のP450を非競合的に阻 害した場合、その薬物は、相互作用が臨床上問題になる可能性があ る。誘導については、ヒト肝初代培養系などを用いることにより、 ある程度の予測が可能である。

発表では、上記に関する具体例を示し、ヒト試料を用いた相互作 用の予測に関する現状と問題点についてふれたい。

文献

1) 千葉 寛、薬物代謝に関しての薬物間相互作用の基礎知識、治療、76:2214-2220、 1994

2）千葉 寛、P450を介した薬物相互作用、ファルマシア、印刷中

3）千葉 寛、ヒトP450分子種同定：臨床薬理学及び医薬品開発における意義、薬物 動態、10:381-402、1995 